Leder, Arie C.

University of the Free State

\title{
Presence, then the Covenants \\ An essay on narrative and theological precedence Part One
}

\begin{abstract}
Against the background of post-Reformation covenant theologies, this essay argues that the covenants depicted in Genesis through Kings (GK) appear in the context of the prior and more fundamental depiction of divine presence, and that the covenants appear where they do to depict how God secured his own presence on earth without which the renewal of an already, but now defiled, existing relationship is impossible. In order to demonstrate this thesis I describe a contemporary discussion of covenant theology rooted in pot-Reformation discussions, then give reasons for limiting this study to GK, following which I examine the narrative shape of GK and its consistent primary interest in the divine presence.
\end{abstract}

\section{INTRODUCTION}

The priority of the covenant in biblical theology is rooted in Reformation and Post-Reformation theologies, notably that of Cocceius. ${ }^{1}$ Recent Old Testament ${ }^{2}$ and theology exemplify twentieth century covenant-centered theologies. A recent article by Stek argues against the "overload" of covenant in Reformed theology, ${ }^{3}$ as, for example, in Spykman's dogmatics. Bartholomew's defense of Spykman's covenant-centered theology argues that $20^{\text {th }}$ century covenant studies can be combined with the inherited federal theology, ${ }^{4}$ that the covenant of works is found in Genesis 1-2, and thus determinative for the subsequent reading of the pentateuchal narrative. ${ }^{5}$

But neither Genesis nor the rest of the OT explicitly depicts a covenant with Adam; only Hosea 6:7 links Adam to a covenant, but not without interpretative problems. ${ }^{6}$ Not so the other,

1 For a discussion of Cocceius' views of the covenants see Van Asselt (2001:248-270) and Diemer (n.d).

2 Eichrodt (1961:36-44) and Spykman (1992:11-12, 92-95, 259-265)

3 Stek (1994:12-41).

4 Bartholomew (1995:11-33)

5 Bartholomew (1995:14-16, 31-32) and Bolt (2007:171-189).

6 "It is remarkable that Cocceius never appealed, either in his systematic work or in his commentaries, to Hosea 6:7 as a locus classicus for the doctrine of the prelapsarian covenant ('Et illi, ut Adam, transgressi sunt foedus'). He does quote it, but refrains from deciding whether $u$ t Adam should be translated as a proper name, or as a general reference (ut homo). In his view both translations are possible". Van Asselt (2001:250n3). Aalders (1939: 147-152) argues that Hosea 6:7 refers to Adam's transgressing of a bilateral covenant, but concedes that "in the light of Hosea 6:7 we still have to return to the first chapters of Genesis to understand the form of the very first covenant" (1939:149). Ridderbos acknowledges that Reformed dogmatics has not only located the covenant of grace immediately after the fall into sin, but also in eternity itself, with the result that Reformed dogmatics "of the covenant of grace, which commenced after the fall, reached back to the original relationship between God and humanity, rooted in the image of God, and called it, in analogy to the covenant of grace, the covenant of works. And, linking itself to Paul's profound thought about the first human Adam, and the last human, Christ in Romans 5:2-12 and 1 Corinthians 15:20-22; 45-49, Reformed dogmatics developed the doctrine of the covenant 
clearly depicted covenants. The covenant with Noah is crucial to understanding Genesis, and the covenants with Abraham are crucial to the Pentateuch in its development of the patriarchal promises sealed with Abraham and subsequently promised to Isaac and Jacob. The Sinai covenant initiates a unique administration of the relationship between God and Abraham's ${ }^{7}$ descendants in response to Egypt's threaten to annihilate Israel. The covenants with Abraham receive less attention in Joshua-Kings. There the Sinai covenant comes to the fore in terms of the "law of Moses" which, according to Deuteronomy, summarizes Sinai's instructions for life in the land. Israel's syncretistic administration of the covenant leads the Lord to exile them from his presence. At the end of Joshua-Kings Israel shares the lot of the nations (Hos 8:8-10): chafing in exile from God's presence as descendants of Adam and Eve.

Similarly with Adam's sin. Although he is clearly the father of humanity and is thus a figure with universal implications, nowhere does the OT give his sin the attention it receives from Paul. It is rather, Israel's construction of the golden calf at Sinai, the location of calves for worship at Dan and Bethel, and Israel's fascination with other gods that defines the sin that corrupts the relationship between God and his people. It is Israel's, not Adam's, transgression of the Sinai covenant and its restoration in Exodus 34 that resonates throughout GK and the Twelve. ${ }^{8}$ From the point of view of the narrative's development, covenants become crucial only when it begins to treat the divine commitment to secure a safe haven from the consequences of the disorder of human failure to heed divine instruction. Covenant is one mode of representing the relationship between God and humanity-Israel. ${ }^{9}$ But is it primary among other such representations?

Terrien argues that covenant consciousness only appears sporadically in pre-exilic literature as a minor theme in the major prophets. Furthermore, although the prophets spoke with

the conviction that the Sinai covenant had been violated, and though many of their speeches reflect the structural patterns of covenant formulation, the thrust of their religious passions and the source of their interpretation of history lay elsewhere. They were grasped by the presence of Yahweh and they were animated by the dynamics of his word. ${ }^{10}$ Terrien depends on a historical reconstruction of the emergence of biblical themes which locates covenant as emerging late in Israel's history and presence much earlier. This essay argues for the primacy of presence over the covenants on the basis of the narrative organization and presentation of these themes.

in order to bring to light the difference and similarities between creation and recreation, the covenant of works and the covenant of grace" (1949:291). This and subsequent translations are mine.

7 This essay ignores the differences between the names in Gen 15 and 17, and therefore uses "Abraham" and "Sarah" throughout.

8 The golden calf episode recalled by Jeroboam's building of the calves at Dan and Bethel (1 Kings 12:2533) and the echoes of Ex 34:6-7 in Hos 11:8, 14:3; Joel 2:13; Jonah 4:2 and Nah 1:3. Even then Paul reads the Adam Christ typology against the background of a theology of divine presence in his ecclesiology. But when he develops the covenants, Paul works with the universal implications of the Abraham covenant, not with Noah or Adam. Disobedience to divine instruction defiles the presence of God and therefore humanity is expelled. Without the specifics of covenant law as developed in the OT narrative, the covenant cannot explain exile as the result.

9 Ridderbos (1949:292-293) writes: "We must observe, however, that this overall relationship between God and humanity as defined by the doctrine of the covenant, is not exclusive. That is, covenant thought is not the only image that depicts this life-relationship. . . Covenant thought does not drive other images into the shadows. Rather, one should say that covenant thought represents a particular aspect of that relationship." Emphasis added.

10 Terrien (1978:25). 


\section{GENESIS - KINGS AS THE FUNDAMENTAL NARRATIVE}

There are several reasons for limiting this essay's study to GK. First, for some time scholarship has treated GK as a distinct unit, labeling it the Primary History (PH) or the Enneateuch. ${ }^{11}$ Previously scholars discussed a Tetrateuch and a Deuteronomistic History, excluding Ruth; a Hexateuch and Judges-Kings, also excluding Ruth; or as a Pentateuch and Deuteronomistic History (DH), with Deuteronomy doing double duty as the conclusion of one unit and the beginning of another, some even including Ruth among the prophets. ${ }^{12}$ Although the MT tradition delivered a unified prophetic corpus following upon torah, critical proposals concerning the $\mathrm{DH}$ distinguished the narrative from the poetic prophetic literature, in effect moving this material closer to the Pentateuch. After the Pentateuch depicts Abraham's descendants in the pre-land mode of waiting, ${ }^{13}$ the Former Prophets depict Israel in the Promised Land from its entry to its exile. The juxtaposed sequence of individual books of the Pentateuch and the Former Prophets provide a narrative in general chronological order that covers the time from the creation and Adam and Eve's exile in Genesis, to Judah's exile from God's presence in 2 Kings.

Second, this Pentateuch-Former Prophets complex ${ }^{14}$ now forms the received canonical history of Israel in which the Former Prophets, with themes enunciated by Deuteronomy, evaluates Israel's life in the land in terms of torah. Framed by an exile from the Garden presence and expulsion from the divine presence as experienced in the Promised Land, this history provides a normative raison d'être for Israel's exilic and post-exilic self-understanding by which the subsequent generations of God's people are urged to repent and to call upon the name of the Lord wherever they may be (1 Kings 8:22-53, esp. vv 46-50).

Finally, GK provides a limited but unified narrative in whose weave the threads of divine presence and the covenants may be examined to provide a sufficient argument for the primacy of presence. It also has the merit of moving beyond Terrien's beginning with the patriarchal narratives to include those chapters crucial to the debates about the role of covenant in federal theology. ${ }^{15}$

My reading of GK understands that its themes, however they may have developed historically, now enjoy a systematic relationship embedded in the received text and that these are capable of examination on the basis of a close reading of the received narrative. ${ }^{16}$ Arguments for the pervasiveness of the covenants depend on the reading of Genesis 1-3, for it is here according to federal theology, that the covenant structure of reality is disclosed. Such arguments should be tested against these texts but also in the context of how these opening chapters initiate, define, and emplot the GK narrative as a whole. That is, tested against the narrative problem ${ }^{17} \mathrm{GK}$

11 Schmid (2006:1-14), Freedman \& Kelly (2004:39-47), Mandell \& Freedman (1993:81-142). Zenger (2006:177-178) argues for a deuteronomistically inspired exilic history, Gen 2:4b-2 Kings 25. See also Römer \& Schmidt (2007).

12 Zenger (2006:222-229).

13 Leder (2010a).

14 Ruth's canonical location, among the Former Prophets in some Bibles, does not affect the thesis of this essay. For its canonical effect in the Former Prophets, see Leder (2002:20-22).

15 As Israel's canonical historical account GK also defines basic theological themes, first of all in the Pentateuch, and then drawn through the Former Prophets. Rendtorff (2001) defines ten fundamental theological themes: creation, covenant and election, the patriarchs, the Promised Land, the first and second exodus, torah, cult, Moses, the Davidic kingdom, and Zion. Eight of these arise from the Pentateuch, the last two from the Former Prophets. Each theme is examined as it develops through the canon.

16 Rendtorff (2005:2-3, 415-417), Knierim (1995:190), Fokkelman (1999), and Alter (1981).

17 "The full-grown story begins by establishing a problem or deficit; next it can present an exposition before the action gets urgent; obstacles and conflicts may occur that attempt to frustrate the dénouement, and finally there is a winding up, which brings the solution of the problem or the cancellation of the debt" 
formulates in its opening chapters, and to what resolution it takes the reader at its conclusion.

\section{LITERARY STRUCTURES AND THE DEPICTION OF DIVINE PRESENCE}

This section examines those texts and their features that suggest GK's leading interest in the presence of God: the overture to GK in Genesis 1:1-2:3; the literary frame of GK as set forth in its opening and closing chapters; consecrated spaces such as Noah's ark, the tabernacle, and the temple, constructed in compliance with divine instruction; the Sinai pericope; and, Kings' treatment of the temple.

\subsection{Compliance in the presence of heaven: Genesis 1:1-2:3 as overture}

The ten-fold toledoth structure which begins in Genesis $2: 4(5: 1 ; 6: 9,10: 1 ; 11: 10 ; 11: 27 ; 25: 12$; $25: 19 ; 36: 1 ; 37: 2)$ sets Genesis $1: 1-2: 3$ apart from and makes it the basis for the subsequent narrative development. In two groupings of five, these toledoth provide an interlinked narrative describing how Adam and Eve and their descendants respond to the opening divine speech (2:4-11:26); and then how Abraham and Sarah and their descendants (11:27-50:26) respond to the Lord's speech in 12:1-3. Both pentads include heaven's response to action on the earth: the flood and the covenant to secure the earth from further divine water judgment and Babel; the covenants to secure the promises to Abraham. As the overture to Genesis, chapters 1:1-2:3 also become the overture to the rest of the Pentateuch and, subsequently, the Former Prophets; in sum, the entire GK.

The Genesis overture is narrated from the perspective of one who overhears the divine commands, uttered in the heavenly council; 18 the word is spoken and created reality comes into being. Distinct from its creator, created reality is sacred: its structure by fiat and its function by sabbatical sanctification and blessing. A series of command-compliance sequences, in the mode of "Let there be . . . and it was so", (1:3, 6-7, 9, 11, 14-15, 20-21, 24, 26-27, 29-30), characterizes the divine speech which brings this reality into being. That is, the overture depicts heaven's structuring of the earthly reality which obtains for all creatures, including humanity, and the subsequent account narrates humanity's earthly response in variations of the overture's instruction-compliance theme. Humanity comes into being as do all other creatures, by divine fiat, but only humanity receives the unique capacity for a compliant life in God's presence: the blessing of Genesis 1:28. And, only humanity receives specific instructions for its earthly task (Gen 2:15-17).

Genesis 2:4 through 2 Kings 25 mirrors the instruction-compliance sequence of the overture in several ways. By virtue of its position outside the toledoth structure, the instruction-compliance overture itself functions as an instruction account, compliance to which is developed by the toledoth structure ${ }^{19}$ that depict the earthly response to heaven's instructions in two groupings, one in terms of Adam's (2:4-11:26) and the other in terms of Abraham's (11:27-50:26) progeny. In addition to the instruction of the overture, Abraham's progeny is depicted in the light of the divine instruction of Genesis 12:1-3. The rest of GK continues the account of the response begun in the sixth toledoth. Human response to the divine structure of reality in Genesis 3, flawed and non-compliant, has its Israelite homologue in Exodus 32-34, a failure to heed divine instruction which, unlike the immediate compliance in the Genesis overture, interrupts the instruction (2531) and compliance (35-39) sequence. It also evokes other aspects of the overture.

Fokkelman (1999:77).

18 Stek (1990:235-236).

19 Woudstra (1970:184-189) and Carr (1998:159-172, 327-347). 


\begin{tabular}{|l|l|l|}
\hline Heavenly Instruction & \multicolumn{2}{|l|}{ Earthly Compliance (divine-human interaction) } \\
\hline $\begin{array}{l}\text { Gen 1:1-2:3 } \\
\text { (instruction-compliance) }\end{array}$ & Gen 2:4-2 Kings 25 \\
\hline & $\begin{array}{l}\text { key instruction } \\
\text { (on the earth) }\end{array}$ & $\begin{array}{l}\text { compliance } \\
\text { (divine-human interaction) }\end{array}$ \\
\hline & Gen 2:16-17 & $\begin{array}{l}\text { Gen 2:4-11:26 (Adam \& Eve) - 5 } \\
\text { toledoth with defiling failure to heed } \\
\text { instruction }\end{array}$ \\
\hline & Gen 12:1-3 & $\begin{array}{l}\text { Gen 11:27-50:26 (Abraham \& Sarah) } \\
-5 \text { toledoth, various failure to heed } \\
\text { instruction }\end{array}$ \\
\hline & $\begin{array}{l}\text { Ex 19-Num 10 } \\
\text { (Sinai pericope) }\end{array}$ & $\begin{array}{l}\text { Ex 1:1-2 Kings 25 } \\
\text { with defiling moments: failure to heed } \\
\text { Sinai instruction, baalization of north } \\
\text { and south. }\end{array}$ \\
\hline & \multicolumn{2}{|l}{} \\
\hline
\end{tabular}

As the instruction-compliance sequence in Genesis culminates in the seventh day of rest which God sanctifies and blesses (1:31; 2:1-3), so the instruction-compliance sequence in Exodus 25-39 includes the sanctification of Israel and the sabbath (Ex 31:12-17; and see 35:1-3 on sabbath), and Moses' blessing of Israel (39:43), thus evoking the seventh day of the Genesis creation account. ${ }^{20}$ Exodus concludes with an uninterrupted instruction-compliance sequence in chapter 40 which depicts Moses's assembly of the tabernacle, thereby recalling Genesis 1:1-2:3. The tabernacle's purpose is to allow God to dwell in the midst of his people (Ex 25:8). The evocations of Genesis 1:31 and 2:1-3 at the end of Exodus remind the reader of the creation brought into being by divine instruction-compliance. These echoes also suggest that Israel should understand its identity and relationship to the designer of the tabernacle as analogical to that of humanity in Genesis 1:26-28. ${ }^{21}$

Stek has cogently argued that Genesis 1:1-2:3 functions as a theological overture to Genesis and that it depicts the royal acts of a great king who subsequently administers his earthly kingdom by means of the covenants with Noah and the Abraham. ${ }^{22}$ Given the royal metaphor,

* Note the pervasive character of instruction-compliance throughout narrative. For example, the seven speeches of tabernacle building instruction in Ex 25-31 and the subsequent compliance in 35-39, mirrored in 40:1-16 and 17-33; the phrase "and 'so and so' did as the Lord/Moses commanded" in Lev 8-9 and throughout Num 1-10; the repetition of instructions and compliance such as in Josh 3-4 and 6. Noth argues (1981:89-99) that the DH vindicates God's judgment on a people who failed to comply with divine instruction.

20 Parallels between Ex 39, 40 and Gen 1:31-2:3 are well-known. See Weinfeld (1981:501-512), Janowski (1990:45-47), and Zenger (1987:170-172).

21 This discussion is important vis-à-vis the legal understanding of the putative covenant relationship between the Creator and the creature. See the discussion below.

22 Stek (1990:232-240). Rendtorff (1998:79) suggests that the lack of a plural for "covenant" makes it difficult to talk about different "covenants". While this is true in the sense that one could argue that the Abrahamic covenant is a subset of the Noahic covenant in that the former is made with a subset of the latter's descendants, the covenant with Abraham in Gen 15 responds to the promises of Gen 12:1-3. Furthermore, although the covenants subsequent to Gen 15 may be understood to be various expressions of the one covenant God made with Abraham, it is important to recognize the different kinds (royal grant or suzerain-vassal) and different narrative roles of these covenants. Last, it is not unimportant that Paul 
defining humanity as "appointed to a royal station in the creation", as "vice-regents", or as "regal servants" 23 rings true. Others, ${ }^{24}$ however, consider Genesis 1:1-2:3 to depict creation not in royal throne-room but in sanctuary terms. Where the royal metaphor is conducive to federal theology's focus on the covenant because it is congenial to suzerain-vassal thought, the change in metaphor invites a rethinking of the identity of the relationship between the Creator and the creature. Is the royal metaphor exclusive or sufficient for an understanding of human identity? What happens when we factor in the theme of divine presence?

The ancient world understood human kingship to be intimately related to the gods. In Mesopotamia the king had sacred duties; in Egypt the king was divine. ${ }^{25}$ Both, however, extended divine authority to earth, a geography subordinate to heaven alone. The divine kingship of the Creator of Genesis 1:1-2:3, however, is not subordinate to any created reality, nor is it an expression of an eternal principle of order to which even the ancient gods were subordinate. The very act of creating underscores the incomparability of the Creator. Where human kingship participated in the construction of an earthly sacred space by following heaven's design, the biblical Creator merely instructs and reality comes into being. Thus Gudea and other old world rulers received designs for sacred construction; failure to comply with the design opened the door to chaos. In the biblical narrative subsequent to Genesis 1:1-2:3, human beings (Noah, Moses, David, Solomon, Jesus [John]) also comply with divine instruction to construct redemptive spaces within the created order. Failure to comply with the divine instruction ultimately brought chaos, the destruction of Jerusalem and the temple and exile.

Although depicted as a Great King (Ps. 48:2) of the earth, the Creator of Genesis 1:1-2:3 is not like other Great Kings who are "divine" in their own right, as those Pharaohs discovered who challenged that divinity with their own. The Creator is the ruler whose commands originate with him; he receives them from no other as did the occupants of ancient divine kingship. He has no dynastic antecedents, neither in heaven nor on earth. This depiction God's divine kingship coincides with that of the creation as a sanctuary. Within this metaphor, earth and all that is in it is sanctified unto exclusive service of the one and only Deity, with humanity cast as the Deity's image.

All this being the case, the question arises: Is the royal aspect of the depiction of the Deity sufficient for understanding human identity and function? And, is it necessarily a covenant relationship? ${ }^{26}$ If the metaphor for understanding creation is sanctuary space, is it not true that humanity would relate to the Creator primarily, not as a vassal to a suzerain, but as a priest to a deity, a deity who expects the subordinates in his presence, wherever they may be on the

uses the plural: "They are the Israelites, and to them belong the sonship, the glory, the covenants ..." (Rom 9:4).

23 Stek (1990:231), and see Waltke (2007:220, 232), Spykman (1992:265-266), and the oft cited Gerhard von Rad (1972:57-60).

24 Hurowitz (1985:25-27), Wenham (1987:29-32), Walton (2009:78-86) and Smith (2010). Hurowitz

(1992:241-242, esp. footnote 2) indirectly suggests that the genre of Gen 1:1-2:3 is temple building account. Waltke (1991:2-10) reviews the following suggestions: hymn, cult liturgy, myth, history, science, and theology. He concludes that it is best to describe Genesis 1 as a "literary-artistic representation of the creation, ... to ground the covenant people's worship and life in the creator". Koole (1963:116) suggests that Genesis 1 has "neither literal nor illustrative meaning. It is very likely borrowed from Israel's wisdom traditions, or, expressed theologically: Genesis 1 describes (betekent) the lawfulness of Israel's nature wisdom". (translation mine) Young (1976:15-16) describes Genesis 1 as a creation account in terms of fiat and fulfillment. He acknowledges Sumerian documents speak similarly, but dismisses the relationship on the grounds of Scripture's uniqueness.

25 Frankfort (1948:3-12, 51, 231).

26 Stek (1994:25) lists at least seven relationship types "that included mutual obligations in ancient Near Eastern society that were not considered 'naturally' to be "covenants." 
earth, to comply with instructions to maintain the cleanliness of the divinely prepared space? Is it not possible to understand the Creator-creature relationship in deity-priest terms? Is it not possible that the metaphor depicting the deity contains elements transparent to the ancient world, elements traditionally not associated with human identity in Christian, especially federal, theology?

These questions are pertinent because the people in whose midst God dwells at Sinai-like humanity on the seventh day, and Adam and Eve in the Garden-is identified as a kingdom of priests and a holy nation (Ex 19:6; cf. 1 Peter 2:5 ["a spiritual house to be a holy priesthood"]). The priestly character of God's people receives extended attention in Leviticus: compliance with sacrificial, cleanliness, and holiness instruction keep them in God's presence. Israel's time at Sinai underscores primarily her priestly, not her royal, character. Post-lapsarian life in exile from God's presence is possible only in the sanctuary space designed by God; and only priests may enter it.

Smith argues in favor of a combined priestly and royal identity for humanity on the basis of the two verbs implicated in the discussion about human identity, "to rule" $(r d h)$ and "to subdue" $(k b s ̌) .{ }^{27}$ In his iconographic study of the nouns "image" and "likeness," Herring argues that humanity, as an extension of the deity, could be understood to be priestly:

The function or purpose of making humanity as the extension of the deity is found in the

blessing to create a humanity which produces progeny in keeping with that image and

likeness and, further, is to kbš ("subdue") and rdh ("rule") over the cosmic temple. It is the

caretaker over the cosmos/temple-precinct, a role sometimes assumed by lower deities in

ancient temple consecration myths and by the priesthood in ancient Israel. ${ }^{28}$

This priestly identity of humanity illuminates the reason for and nature of redemption by means of divinely constructed redemptive spaces. When the narrative switches to what became of the cosmic sanctuary in the first toledoth (Gen 2:4-4:26) it does so from an earthly viewpoint to depict the caretakers' response to the instructions for life in the cosmos/temple-precinct (Gen 2:8-13; cf. Ezek 45; 47:1-12). In the deity's close presence (Gen 3:8, pny) priestly humanity may safely dwell by complying with divine instruction and thus keeping disorder at bay. Such is humanity's liturgical and doxological duty.

Adam and Eve's non-compliant response defiled the divine presence for which God drives them, and their descendants, into deadly exile from his presence (3:23). Cherubim with fiery sword prevent re-entrance to the garden presence; now all receive the wages of transgression for all are born east of Eden. This forced distance from the divine presence continues with the tabernacle and the temple where guardian cherubim embroidered into the tabernacle curtains (Ex 26:31; 36:8) and carved on the walls of the Jerusalem temple (1 Kings 6:29) prevent entry except for Israel's priests. Exile of priestly humanity from the presence of God for failure to heed divine instruction is the narrative problem which Genesis defines and which the rest of GK develops. The solution to the problem is nothing less than God's returning Adam and Eve's priestly descendants from exile into his presence, first at Sinai and later Zion. On the journey from Sinai to Zion God indwells his people by means of the tabernacle-temple. But GK ends where it began: God allows Zion to be destroyed and removes Judah from his presence (Ipny, 2 Kings $17: 18,23 ; 23: 27 ; 24: 3,20)$, not the land, into exile.

27 Smith (2010:71, 98-101).

28 Herring (2008:491), where he identifies Gen 2:15 as describing such a caretaker role, and the verbs cbd

("serve") and šmr ("guard") as often describing the duties of temple personnel. See also Gupta (2009:67,

70-72) where Gupta develops the theme that 1 Peter urges the church to take seriously its priestly identity

(as recalled by, among other texts, Ex 19:6), in order to fulfill the task to which it has been called. 


\subsection{Failure to comply: earthly exile from divinely instructed presence}

The GK narrative following the overture is framed by two expulsions from God's presence: one from the Garden presence, and the other from the divine presence in Jerusalem.

The narrative of the first expulsion depicts Adam, Eve and their descendants as wandering east of Eden. Humanity was created to live in God's intimate garden presence; reality is that no one lives in that presence anymore, nor can anyone return to it for entrance to that presence is guarded by cherubim with fiery swords. Death stalks everyone. Adam and Eve's firstborn Cain is condemned to even deeper exile $(4: 14,16$ [pny]) for killing his brother; Lamech threatens death to anyone wounding him. From within the burdens of exile people begin calling upon the Lord in the days of Enosh (4:26; cf. Ps 137) and divinely blessed humanity produces many children, but all die (Gen 5). Only wickedness and violence successfully fill the earth (6:7 [pny-h'dmh]; cf. Gen $1: 28)$ in God's presence $(6: 11,13$, Ipny) with the result that God intensifies humanity's exile from his presence with almost universal death in the days of Noah. A subsequent attempt to enter the divine presence at Babel ends in God's scattering Adam's descendants over the face of the earth (11:8-9 [cl-kl-pny-h'rs]), the use of pny perhaps evoking distance from divine presence common to Adam's descendants.

It is God himself who begins to address humanity's exile when he instructs Abraham to abandon the post-Babel exile to go to "the land I will show you". Recognized by all hearers as the Promised Land where Israel dwells in God's presence, this place (like the Garden of Eden, Gen 13:10), not Babel, promises to bring together in God's presence those descendants of Adam and Eve who are blessed in Abraham. But they would not stay in the land forever.

After Moses' instructions on the plains of Moab, Joshua continues the GK by depicting the divine presence as crossing the Jordan before Israel (Josh 3:11,13). Sanctified by this presence Israel's life in the land would be shaped by the Sinai instruction (Josh 1:7, 8; 23:6-8), a commitment renewed at Ebal and Gerizim (Josh 8:30-35) would shape life in the Promised Land. Having been given rest from their enemies (Josh 21:43-45) and received a king, God permits Solomon to build him a temple (1 Kings 6-9), from which earthly temple the Lord would rule from heaven (1 Kings 8). As the tabernacle sanctified the camp in the desert so the temple made the land holy. Thus both kings and people lived in God's presence, the kings being responsible to insure torah cult and conduct for good life in God's presence. After the northern kingship's failure to abide by torah instructions God expels Israel from his presence (Ipny, 2 Kings 17:20, 23). Josiah's subsequent reformation of the cult in Jerusalem could not undo Manasseh's corruption with the result that the Lord also expels Judah from his presence (Ipny, 2 Kings 23:27; 24:3, 20). Chaldean soldiers (2 Kings 25:4-50) drag Judah into the land of exile from which the Lord had rescued Abraham, the son of Nahor, son of Shem, son of Noah, and son of Adam.

The exile-frame of the GK underscores the narrative problem it addresses: humanity's exile from God's presence for refusal to comply with divine instruction. Earthly humanity should comply with heaven's divine instruction in the same way other earthly creatures "naturally" comply with divine command. God's solution meets with stubborn resistance at Sinai and after the dedication of the temple, both with the erection of golden calves; all designed to undermine God's presence and instruction The exile-frame suggests that the descendants of Abraham not only reflect Adam and Eve's non-compliance, but also that they are doubly guilty, having been brought into the divine presence again. Sinai's covenant instruction and commitment was also repeatedly renewed either because of Israel's non-compliance (Ex 32-34; Deut vis-àvis Num), in response to specific instruction (Josh 8:30-35), or as the result prophetic calls to repentance ( 2 Kings 17:7-15). In between the beginning and ending of this narrative frame, we note a development of the theme of divine presence in terms of places of divine presence and instruction. These places address the rupture between heaven and earth depicted by failure to heed divine instruction. 


\subsection{Redemptive instruction for priestly life in exile and in the divine presence}

In the chaos of humanity's stewardship of creation outside God's Garden presence, a more unencumbered life on the earth can only be experienced where God irrupts into this earthly disorder to create room for compliance to divine instruction. GK depicts four such spaces: Noah's ark, the presence shaped journey of the patriarchs (affirmed at altars, anticipate the cult as central), Mt. Sinai, and the tabernacle-ark-temple journey. A brief comment about each follows.

\subsubsection{Noah's ark}

In God's presence (Ipny, Gen 6:11, 13 [cf. 6:8 and Noah]; 7:1) humanity fills the earth with violence (Gen 6:11, cf. 6:5)-the legacy consequent upon disobedience in the Garden-rather than compliance with the instruction that obtains for the earth (Gen 1:28). ${ }^{29}$ Human wickedness occasions the second set of divine instructions: God tells Noah to build an ark in the midst of this non-compliant world. Unlike Adam and Eve, Noah complies (Gen 6:14, 22; 7:5, 9, 16). By designing a vehicle of rescue for "all that breathes" (Gen. 9:10) and shutting them in to prevent the intrusion of chaos (Gen 6:16; 7:15 cf. 3:24), ${ }^{30}$ God provides the only means of rescue from divine judgment on a post-lapsarian world. It also links the pre- and post-diluvian human stewardship of the earth, for life east of Eden continues, but with deadly and fearsome differences (Gen 9:1-7). ${ }^{31}$

True to its inheritance, post-diluvian humanity fails to comply with divine instruction. The prohibition against bloodshed, by humans and animals, suggests that violence has not abated; Ham's seeing his father's nakedness anticipates the transgression of boundaries practiced by the nations and which the Lord detests (Lev 18, esp. vv. 23-30). Humanity's subsequent attempt to build its own access to divine presence ${ }^{32}$ does not escape heaven's notice (Gen 11:5); exile from the Garden does not mean freedom from divine presence. ${ }^{33}$ Heaven foils human ecumenicity by the confusion of languages and scattering Adam's descendants from what they considered the center of the world.

The ark provides continuity for life on the earth in heaven's presence; but it changes little. The ark, even though divinely designed, did not qualitatively affect humanity's enforced flight from God's presence; nor was it God's dwelling place on earth, as was the Garden, the tabernacle, and the temple would be. Rather, because of humanity's abiding wickedness (Gen 6:5-7) the ark narrative argues that humanity's wandering will end in death. But then God promises righteous Noah a covenant. ${ }^{34}$

\subsubsection{A presence shaped journey}

From among the exiled and scattered nations God selects Shem's descendant Abraham. With him and Sarah the narrative turns the depiction of a forced wandering away from God's Garden presence into an instructed journey towards God's presence. God's third word of instruction since Adam, and first since Noah-"Leave (lk-lkh) your country . . . and go to the land I will show

29 See Knierim (1995:186-191) and his discussion of the distinction between the heaven and earth, and that creation orderliness obtains for human history.

30 See Keel (1997:120-127) on the role of gates.

31 Gen 6-9 recalls the covenant in early chapters of Genesis, Bartholomew $(1995: 23,26)$.

32 The Babel-ziggurat evokes temple-mountains Keel (1978:113-120) which in Gen 11 reflects human attempts to reach heaven and thus transgress a fundamental boundary. On the crucial distinction and separation of heaven and earth see Knierim (1985:190-191).

33 Nor enforced compliance with the instruction to "fill the earth" (Gen 1:28). Humanity's "natural" response to that instruction fills the earth with violence (Gen 6:11,13).

34 The covenant with Noah will be treated in the second part of this essay 
you"-receives immediate compliance: "So Abraham left". 35 This compliance signals a complete separation from the enforced flight from God's presence because the divine instruction aims Abraham and his descendants at "the land", a geography emblematic of God's presence. Once in the land, the Lord appears $\left(r^{\prime} h\right)$ to Abraham $(12: 7 ; 15: 1 ; 17: 1 ; 18: 1)$ to affirm the promise of land and progeny. Divine visitations to Isaac and Jacob recall and confirm the promises to Abraham (26:23 [r'h]; 28:13; 35:1, $\left.9\left[r^{\prime} h\right] ; 46: 1\right)$, and encourage their imitation of Abraham's submission to leave the confused culture of Babel and go to "the land". In Genesis Abraham and his descendants move towards "the land", only to end up in Egypt. Generations will pass before they possess "the land".

The initial instruction to Abraham in Genesis 12, the instruction to walk in God's presence (17:1, hthlk Ipny), and the subsequent divine appearances to Isaac and Jacob, suggest that not the dogged endurance and patience of the patriarchs, but the divine presence alone, shapes the journey. The narrative suggests this by the initial promise and the often repeated instructions, and by protecting the patriarchal community from contempt (Gen 12:2, qII), from without (Gen 12:10-20; 20; 26:7-11; Ex 1:8-14; Num 22-24) and from within (Gen 27:35; 34:30; 37:19; Ex 32:1-14; Num 13-14; 25), through the entire journey, from Abraham's first entry to Egypt to the borders of the Promised Land. Although not a space like Noah's ark, Abraham and his descendants' journey is a "way" (drk: Gen 18:19; 28:20; Ex 23:20; Num 22:32-34; Deut 1:33; Josh 3:4; 24:17; 1 Sam 12:23; Neh 9:12, 19) which God secures by his presence, as vouchsafed to Abraham: "I am your shield", and Abraham's commitment to walk in God's presence blamelessly (Gen 15:1; 17:2). This "way" is qualitatively different from that of the wicked (Ps 1:6; Prov 2:8; $4: 18-19 ; 10: 29 ; 16: 2,7,9$ ). Along this way the patriarchs build altars (Gen 12:8; 26:25; 28:18; $35: 7)$ to memorialize their infrequent experience of God's presence. These altars, and later the Sinai and Zion cult, connect the subsequent generations to the patriarchal memory of God's presence as they continue on the "way" with Abraham. ${ }^{36}$ Terrien, interprets the new direction as follows:

Man's attempt to obtain territorial security has failed. The figure of Abraham is introduced as the embodiment of a new form of society which deliberately severs its bonds with a static past in order to experiment in time ... . [The] "blessing" of Abraham and the "blessing" which Abraham is called upon to become are the blossoming of a moment of divine proximity, and the response to the epiphanic speech constitutes the Hebraic stance of faith. All the other stories of epiphanic visitation to the patriarchs introduce the theme of the testing of that faith. Because the fulfilment of the blessing is delayed and the selfdisclosure of Yahweh remains limited to short instants of visitation, the Hebraic theology of presence at once acquires the elements of absence or at least hiddenness. From the start of the tradition regarding the history of salvation, cultus and faith are inextricably bound. ${ }^{37}$

From Abraham's departure to Jacob's descent into Egypt, "the land" has been central in the narrative development and definition of the "way", but none of the patriarchs achieves possession; inheritance remains in the background. With the descent into Egypt the land is forced into an even deeper background, with the result that a new geography begins to move into the center: the desert and, within it, Sinai. These two will significantly redefine the "way" of Abraham's descendants in God's presence.

35 The syntax of the intervening clauses (simple waw, cohortative plus imperatives in Gen 12:2-3) points to the intended result of the instruction: progeny, reputation as blessed of the Lord, security against curses, medium of blessing for all the families of the earth.

36 "It is not that significant persons from salvation history become altar builders (through the process of redaction), but that altar builders become decisive persons of salvation history" Riecker (2006:530).

37 Terrien (1978:73-76). 
Heaven's blessing of Jacob's descent into Egypt (Gen 46:2-4) is the last divine self-disclosure in Genesis, and the only one that occurs in the Joseph story. God does not address Joseph or his brothers; they depend upon their own wits for survival. That God is involved and that his presence still embraces the way is undeniable (Gen 39:3, 5, 21, 23; 46:4), but it is a muted, veiled presence which protects the "way." In Egypt, the promise of growth is partially fulfilled, enough to evoke opposition, so that the people on the "way" are persecuted. But, as Joseph's suffering brought life to the patriarchal family, to Egypt, and the whole world (Gen 41:56, 57), so Israel's depicted suffering in Egypt describes the initial forging of a new identity in God's presence on the way to, at, and after Sinai. Within this new identity, ultimately, the nations will receive the promised blessing (Gen 12:3; John 1:14; Gal 3:29). In Egypt God begins a series of self-disclosures that climax in Israel's own terrible desert encounter with the consuming-fire God of their salvation.

\subsubsection{The desert-Sinai presence}

By narrative location and impact the Sinai event theophany is singular. Set off by two desert journey narratives (Ex 15:22-18:27; Num 11:1-22:1), Israel's time at Sinai depicts the instruction needed to survive in God's presence. The Sinai instruction consists of four distinct parts: Israel's arrival in the deadly presence and subsequent oath-bound expression of loyalty to the Lord (Ex 19-24); the instruction for building the Lord's dwelling among Israel, compliance with instructions after an Eden-like failure to submit, and the glory cloud's indwelling of the tabernacle (Ex 25-40); sacrificial, cleanliness, and holiness instructions for survival in the presence of God (Lev 1-27); and, the organization of the camp and departure from Sinai in the presence of God (Num 1-10).

By bringing Israel into the desert God removes Israel from the nations' influence, neither Egypt nor Canaan may contribute to Israel's identity (Lev 18:1-5). Religiously equidistant from Egypt and Canaan, the exile of these descendants of Adam and Eve has come to an end, for in the desert they are brought into the presence of the God of Abraham, Isaac and Jacob, the God who rescued them from Egypt, the God who spoke all things into being who first instructed Adam for life in his presence (Ex 19:4). This geo-religious separation from Egypt makes Israel completely dependent in God's desert presence. ${ }^{38}$ It is also in that desert presence at Mt. Sinai that heaven speaks without interference from the nations; but Israel herself does (Ex 32). From the meeting place of heaven and earth on Sinai's summit, God invites Abraham's descendants to bind themselves to him, and not to Pharaoh or any other gods; to build him a place so he can dwell in their midst. At the mountain in the desert, the problem of exile from God's presence is partially solved for these descendants of Adam and Eve.

Sinai redefines the patriarchal journey in unexpected ways. Oath-bound loyalty to the Lord replaces subservience to Pharaoh; the relatively uncomplicated cult associated with patriarchal epiphanies is refocused on divine appearances at the tabernacle (Ex 29:42-46); Israel's golden calf construction reveals its own Pharaoh-like stubbornness (Ex 33:3, 5) and threatens the journey (32:9-10; 33:15-16); the Lord's dwelling in her midst creates redemptively consecrated space for Israel's safe existence in which life is shaped by sacrifice, cleanliness, and holiness. Israel's experience of God's Sinai good but dangerous presence changes her environment profoundly: the people who leave Sinai now have this good but dangerous God in their midst and everything they do in their lives is shaped by his holiness. For that reason Israel remains at a certain distance from God. The cherubim still prevent entry to his immediate presence (Ex 26:1, 31; Gen 3:24); priests will perform liturgical rituals in God's closer and closest presence, and Levites will surround the tabernacle to prevent God's anger from breaking out against Israel (Num 1:53).

38 Leder (2010b:306-307). 
Just like "the man and his wife heard the sound of the Lord God as he was walking (hthlk) in the garden in the cool of the day" (Gen 3:8), so the Lord walks about in Israel's desert camp:

"I will put my dwelling place among you, and I will not abhor you. I will walk (hthlk) among

you and be your God, and you will be my people" (Lev 26:11; cf. Deut 23:14).

At Sinai the patriarchal community has received instruction for a clean cult and holy conduct in God's presence in the camp and the land of promise (Num 5:3; 35:34). Israel leaves Sinai fully instructed only when the ark of the Lord, symbol par excellence of the Lord's presence, begins the journey that will take them to the land (Num 10:33-36).

\subsubsection{From Sinai to Zion: the ark}

The journey from Sinai comes to a completion only when the priests carry the ark into the Holy of Holies of the temple Solomon built on Mt. Zion. The ark links Sinai and Zion; it connects one meeting place of heaven and earth with another: to Sinai God graciously draws the descendants of Adam and Eve through Abraham and Sarah; to Zion the law attracts other descendants of Adam and Eve (Is 2:3; Ps 102:18-22). The ark's journey from Sinai has three parts: into the desert towards the land but ending in the plains of Moab; entry into the land; and its sojourn in the land until it rests in the temple.

The journey is in fact a royal victory march, ${ }^{39}$ begun with God's triumph over Egypt, which continues in battle mode (Num 10:35) and includes victories over Arad, Sihon, Og, and Balak (Num 21:1-3; 21-30; Num 22-24) before entry into the land, and later over Jericho and the Canaanites (Josh 6, 9-11), Israel herself and the Philistines (1 Sam 4:1b-7:1; cf. Num 14:41-45; 2 Sam 8:1-14) before it rests in the building that memorializes his victories over the nations (1 Kings 8:6-11, 56). During this journey the Lord's special guard (Num 3:21-37) escorts the earthly manifestation of the divine presence, itself at the center of the camp surrounded by the battle divisions according to the various tribes (Num 2:1-34, esp. v. 17), from its desert manifestation to the center of the earth at Jerusalem (Ps 48:2). And, even as the Sinai presence was the partial solution to the problem of exile for the descendants of Abraham, so Zion promises a greater reality of rest for the descendants of Adam and Eve, for from it emissaries will make the Lord's claims upon all the nations of the earth, and to it all the nations will come to acknowledge the Lord (Is 66:20; Ps 72:8-11) who reigns over all the earth from heaven (1 Kings 8:30, 33-34, 38-39, 42-43, 44-45, 48-49).

Even as the Lord's powerful presence in Israel's midst consecrated Israel to him in the desert camp, so the entry into Canaan of the true king of heaven (Josh 2:11) consecrates the land and its inhabitants (Num 5:3; 35:33-34), with the result that the unclean descendants of Adam and Eve in Canaan are devoted to destruction (Josh 6:17-19; 11:12-23; Lev 18:24-28; 20:20-23; Deut 7:2). The ark's crossing the Jordan into the land discloses the nations' future with the God of Israel: the inescapable judgment for failure to comply with divine instruction in the divine presence brings death (Gen 2:15-17), unless they have the integrity to commit treason to their Adamic inheritance, as did Rahab, Ruth and Naaman (Josh 2:8-14; 6:17; Ruth 1:8, 16; 2:11; 2 Kings 5; cf. Gen 12:1). Deceit, like that of the Gibeonites, has its own consequences (Josh 9:2223). The Lord consecrates Israel with the little death of circumcision before it wields the sword of the Lord against the Canaanites, and afterwards it renews its covenant loyalties (Josh 5:2-9; 8:3035). After concluding the wars of Canaan, the Lord gives Israel rest from its enemies (Josh 21:44).

But when Israel herself defiles the land by failing to live by divine instruction, the Lord gives the nations rest from Israel's conquest (Judg 2:23; 3:1 [nw]) and allows them to disturb Israel's rest. Failed leadership produces total chaos, until God brings Samuel into his intimate presence (1 Sam 3:3) to begin the restoration. But this restoration does not begin before the Lord allows 
the ark to go into exile in Philistia (1 Sam 4:1-11), the consequence of Israel's corrupt priesthood. Returned to Jerusalem by a jubilant David, the ark remains in a tent, its journey not yet complete (2 Sam 7:6-7, 12-13), until Solomon builds the temple on Mt. Zion, the ark is brought into the temple and the glory cloud indwells the Holy of Holies (1 Kings 8:10-11, 56).

Only at this point is the ark's journey from Sinai complete and the people at rest (1 Kings 8:56). God rules from heaven, but will hear petitions directed to his earthly throne in Zion. But temple service deteriorates under the monarchy: Jeroboam builds anti-temples in the north, Ahab intensifies the drift from Zion with the Baal cult; the prophetic ministry of Elijah, Elisha, and others is dismissed with the result that the Lord removes the north from his presence ( 2 Kings 17:20, 23). ${ }^{40}$ The southern kings Ahaz and Manasseh introduce pagan elements into the Jerusalem temple; Manasseh leads the people in corruption worse than the nations before them (2 Kings 21:9). When not even Josiah's reformation postpones divine judgment, God also removes Judah from his presence ( 2 Kings $23: 27 ; 24: 3,20$ ) by giving his royal city and its temple over to the destruction Canaanite Jericho suffered centuries before.

\section{AS IT WAS IN THE BEGINNING}

The end of the GK story evokes the beginning: God exiles his own people from his presence as he exiled Adam and Eve and their descendants. What both most need and receive by divine instruction-an ark to survive the waters of destruction and a redemptively created consecrated space-they consistently corrupt and reject. There is no one righteous or clean enough to survive God's presence. What then is the point of the GK? How can this narrative of rejection and exile from the divine presence be theologically useful? The key lies in the divine response to humanity's threat to and corruption of the space created for consecrated living: God binds himself to the nations at the time of Noah, similarly with Israel, with the covenants that secure the unending gift of his presence and mercy to all the sons and daughters of Adam and Eve who come into his presence through Abraham and, ultimately, through Jesus Christ (Gal 3:29).

\subsection{Presence, then the covenants}

Part two of this essay will consider a certain set of covenants as they appear in their narrative sequence in GK, and focus especially on their contribution to the narrative depiction of God's response to the problem of humanity's exile from divine presence, as well as the depicted response of Adam and Eve's and, subsequently, Abraham and Sarah's descendants.

\section{BIBLIOGRAPHY}

Aalders, GCh (1939) Het verbond Gods. Een hoofdstuk uit de geschiedenis der openbaring. Kampen: Kok. Alter, R (1981) The Art of Reading Biblical Narrative. New York: Basic.

Bartholomew, CG (1995) "Covenant and Creation: Covenant Overload or Covenantal Deconstruction", CTJ 30:11-33.

Bierma, LD (1996) German Calvinism in the Confessional Age.The Covenant Theology of Caspar Olevianus. Grand Rapids, MI: Baker.

Bolt, J (2007) "Why the Covenant of Works is a Necessary Doctrine. Revisiting the Objections to a Venerable Reformed Doctrine", in GLW Johnston \& G Prentiss Waters (eds.) By Faith Alone. Answering the Challenges to the Doctrine of Justification. Wheaton, IL: Crossway.

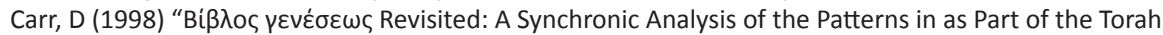
(Part One)", ZAW 110:59-172; 327-347.

40 There is no true temple in the north; it is exiled because it failed to acknowledge Jerusalem as the place of the Lord's presence. 
Diemer, N (n.d.) Het Scheppingsverbond met Adam. (Het verbond der werken) bij de theologen der 16e, $17 e$ en 18e eeuw in Zwitserland, Duitsland, Nederland, en Engeland. Kampen: Kok.

Dozeman, ThB, Römer Th \& Schmid K (2011) Pentateuch, Hexateuch or Enneateuch? Identifying Literary Works in Genesis through Kings. Atlanta, GA: Society of Biblical Literature.

Dumbrell, W J (1984) Covenant \& Creation. A Theology of the Old Testament Covenants. Grand Rapids, MI: Baker.

Eichrodt, W (1961) The Theology of the Old Testament, vol. 1. JA Baker (trans.). Philadelphia, PA: Westminster.

Fokkelman, JP (1999) Reading Biblical Narrative. An Introductory Guide. Ineke Smit (trans.). Louisville, KY: Westminster John Knox.

Frankfort, H (1948) Kingship and the Gods. Study of Ancient Near Eastern Religion as the Integration of Society \& Nature. Chicago, IL: University of Chicago Press.

Freedman, DN \& Kelly, B (2004) "Who Redacted the Primary History"? In: C Cohen et al. (eds.), Sefer Moshe. The Moshe Weinfeld Jubilee Volume, Sudies in the Bible and the Ancient Near East, Qumran, and Post-Biblical Judaism. Winona Lake, IN: Eisenbrauns.

Gupta, NK (2009) "A Spiritual House of Royal Priests, Chosen and Honored: The Presence and Function of Cultic Imagery in 1 Peter", PRS 36:61-76.

Herring, SL (2008) "A 'Transubstantiated' Humanity: The Relationship between the Divine Image and the Presence of God in Genesis I 26f", VT 58:480-494.

Hurowitz, V (1992) I Have Built You An Exalted House. Temple Building in the Bible in the Light of Mesopotamian and Northwest Semitic Writings. JSOTSup 115. Sheffield Academic.

Hurowitz, V (1985) "The Priestly Account of Building the Tabernacle", JAOS 105:21-30.

Janowski, B (1990) "Tempel und Schöpfung”, in Schöpfung und Neuschöpfung. JBTh 5:37-69.

Keel, O (1997) Symbolism of the Biblical World. Ancient Near Eatsern Iconography and the Book of Psalms. Winona Lake, IN: Eisenbrauns.

Kline, MG (1968) By Oath Consigned. A Reinterpretation of the Covenant Signs of Circumcision and Baptism. Grand Rapids, MI: Eerdmans.

Kline, MG (1972) The Structure of Biblical Authority. Grand Rapids, MI: Eerdmans.

Knierim, RP (1995) The Task of Old Testament Theology. Method and Cases. Grand Rapids, MI: Eerdmans. Koole, JL (1963) "Het Litterair Genre van Genesis 1-3", GTT 63:81-122.

Leder, AC (2010a) Waiting for the Land. The Storyline of the Pentateuch (Phillipsburg, NJ: Presbyterian \& Reformed.

Leder, AC (2010b) "The desert itinerary notices of Exodus: their narrative, semiotic, and theological functions", EstBíb 68:291-311.

Leder, AC (2002) "Reading the Former Prophets by the Rivers of Babylon", CTJ 37:9-27.

Mandell, S \& Freedman, DN (1993) The Relationship between Herodotus' History and Primary History. Atlanta, GA: Scholars Press.

Noth, M (1981) The Deuteronomistic History. Sheffield.

Rad, G von (1972) Genesis. A Commentary. Philadelphia, PA: Westminster.

Reitsma, J (2005) Geschiedenis van de Hervorming en de Hervormde Kerk der Nederlanden, 4th rev. ed. Utrecht: Kemink.

Rendtorff, R (2005) The Canonical Hebrew Bible. A Theology for he Old Testament. Leiden: Deo

Rendtorff, R (1998) The Covenant Formulary. An Exegetical and Theological Investigation. Margaret Kohl (trans.). Edinburgh: T\&T Clark.

Rendtorff, R (1995) “Die Hermeneutik einer kanonischen Theologie des Alten Testaments", JBTh 10:40-43. Ridderbos, HN (1949) “Het Verbond der Genade”, in GC Berkouwer \& G Toornvliet (eds.) Het Dogma der Kerk. Groningen: Jan Haan.

Riecker, S (2006) “Ein theologischer Ansatz zum Verständnis der Altarbaunotizen der Genesis"', Biblica 87:526-530.

Römer, Th. \& Schmid, K (2007) Les dernières redactions du Pentateuque, de l' Hexateuque et de I'Ennéateuque. Louvain: Peeters.

Schmid, K (2006) "Buchtechnische und sachliche Prolegomena zur Enneateuchfrage"', in M Beck \& U Schorn (eds.) Auf dem Weg zur Endgestalt von Genesis bis II Regum. Fs. Hans-Christoph Schmitt, BZAW 370. Berlin: Walter de Gruyter. 
Smith, MS (2010) The Priestly Vision of Genesis 1. Minneapolis, MN: Fortress.

Spykman, GJ (1992) Reformational Theology. A New Paradigm for Doing Dogmatics. Grand Rapids, MI: Eerdmans.

Stek, JH (1994) “'Covenant' Overload in Reformed Theology”, CTJ 9:12-41.

Stek, JH (1990) "What Says the Scripture"? in HJ Van Till, RE Snow, JH Stek \& DA Young (eds.), Portraits of Creation. Biblical and Scientific Perspectives on the World's Formation. Grand Rapids, MI: Eerdmans.

Terrien, S (1978) The Elusive Presence. The Heart of Biblical Theology. San Francisco, CA: Harper \& Row.

Van Asselt, WJ (2001) The Federal Theology of Johannes Cocceius (1603-1669). Leiden: Brill.

Van Eijnatten, J \& Van Lieburg, F (2005) Nederlandse Religiegeschiedenis. Hilversum: Verloren.

Waltke, BK (1991) "The Literary Genre of Genesis, Chapter One", Crux 27:2-10.

Walton, JH (2009) The Lost World of Genesis One. Ancient Cosmology and the Origins Debate. Downers Grove, IL: IVP Academic.

Walton, JH (1994) Covenant. God's Purpose, God's Plan. Grand Rapids, MI: Zondervan.

Wenham, GJ (1987) Genesis 1-15. WBC. Waco, TX: Word.

Weinfeld, M (1981) "Sabbath, Temple and the Enthronement of the Lord. The Problem of the Sitz im Leben of Genesis 1:1-2:3", in A Caquot \& M Delcor (eds.) Mélanges bibliques et orientaux en l'honneur de M. Henri Cazelles. Neukirchen-Vluyn.

Woudstra, MH (1970) "The Toledoth of the Book of Genesis and their Redemptive-Historical Significance", CTJ 5:184-189.

Young, EJ (1976) In the Beginning. Genesis 1-3 and the Authority of Scripture. Edinburgh: Banner of Truth.

Zenger, E et al. (20066) Einleitung in das Alte Testament. Stuttgart: Kohlhammer.

Zenger, E (1987) Gottesbogen in den Wolken. Untersuchungen zu Komposition und Theologie der priesterschriftlichen Urgeschichte. Stuttgart.

\section{KEY WORDS}

\section{Covenant}

exile

presence

priestly

\section{TREFWOORDE}

Verbond

ballingskap

hede

priesterlik

Contact address:

Prof. Arie C. Leder

Research Associate: Department of Old Testament

Faculty of Theology

University of the Free State

Bloemfontein

South Africa

E-mail: lede@calvinseminary.edu 